\title{
Effects of climate change on the societal benefits of UK upland peat ecosystems: applying the ecosystem approach
}

\author{
Edward Maltby* \\ Institute for Sustainable Water, Integrated Management \& Ecosystem Research, School of Environmental Science, \\ University of Liverpool, Liverpool L69 3GP, UK
}

\begin{abstract}
For centuries, UK peatlands have been subject to competing sectoral land use and resource demands, generally resulting in their progressive degradation. There is now considerable interest in improving their management, especially in the uplands, partly because of their extreme sensitivity to environmental change and partly because of increasing recognition of the range of ecosystem services they provide. A change in emphasis in the research agenda has been detected, shifting from what peat ecosystems are to what they do. This is linked to a paradigm shift in the attitude of governments and, more generally, in civil society, to account for the wider values of ecosystem functioning. The ecosystem approach is used here as a framework to present more integrated thinking about future peatland management. Key questions, identified for societal consideration and debate, are matched to the 12 principles of the ecosystem approach sensu the Convention on Biological Diversity. A case is made for a more functional approach to defining management objectives based on delivery of ecosystem services. A compatibility matrix is used to indicate the possibilities of simultaneous delivery of services and likely incompatibilities among services. A critique is presented of features of UK upland peat ecosystems which characterise their ecological 'status' and societal context in relation to climate-change issues. The relative importance of climate as opposed to human activities in both peat formation and subsequent development remains a tantalising question, the resolution of which is highly relevant to the maintenance of existing peat and possibilities for ecosystem restoration, given changes in the climate envelope. Setting policy priorities requires a strong interdisciplinary evidence base. It also demands greater understanding of the effects of both direct and indirect human activities, as well as climate change, on the ability of upland peat ecosystems to deliver societal benefits, which previously may have been undetected, undervalued or simply taken for granted.
\end{abstract}

KEY WORDS: Peat · Upland ecosystems $\cdot$ Ecosystem approach $\cdot$ Ecosystem services $\cdot$ Climate change Resale or republication not permitted without written consent of the publisher

\section{INTRODUCTION}

Peatlands in the UK have often been the centre of controversy. Differences in opinion have primarily related to proposals for the alteration of peatland use or the continuation or not of activities causing their degradation (Maltby 1980).

For example, the intensive drainage of the Fens (dating back from the 17 th century) for improved agriculture resulted in fierce opposition from wildfowlers, who, for generations, had been harvesting duck for the lucrative London market (Darby 1983). Alongside traditional fishermen, their opposition, including destruction of drainage works, earned them a reputation as the 'Fen Tigers'. Proposals by the Forestry Commission to plant coniferous trees on The Chains, the most extensive tract of blanket bog on Exmoor, and increasing opposition to grant-aided conversion of peat and organic soils to farmland led to the formation, in 1958, of the Exmoor Society, an effective non-governmental organisation (NGO) and lobby group dedicated to maintaining the 'traditional' moorland landscape and its asso- 
ciated rural livelihoods and public access. Afforestation on Exmoor was prevented. The blanket peats of Caithness and Sutherland were not as fortunate, and 67000 ha (17\%) of the peatland were either planted or approved for planting (Stroud et al. 1987) as a result of tax incentives or Forest Grant Scheme approval (Lindsay et al. 1988). The tax incentives have since disappeared and the Forestry Commission now has guidelines to protect blanket bog from further afforestation (Patterson \& Anderson 2000). The appropriateness of particular current or recent management activities remains a cause for concern. Such activities have included peat extraction for horticulture (primarily lowland fens, but also including some lowland bogs, notably the extensive raised mires of Thorne and Hatfield Moors adjacent to the Humber estuary in eastern England), prescribed rotational burning, grazing or overgrazing, predator control, moor-gripping and various recreational uses (Bonn et al. 2009a, Holden et al. 2007). Each has been the focus of more or less acrimonious debate, bringing various conservation objectives into conflict with commercial interests. There is still a need to clarify and more effectively present the evidence from scientific research and management experience to better inform such debate.

The interest in peat has previously been largely sectoral in character, with discussion concentrating on the protection versus production or 'use' argument (Maltby 1997a). There has now developed an unparalleled widening of interest in UK peatlands from government, statutory agencies, NGOs, business, farmers and other landowners, as well as researchers from the natural and social sciences. This interest is due to the increasing awareness of the roles which peat ecosystems might or actually play in the delivery of ecosystem services (Maltby 1997a, Bonn et al. 2009b) and recognition of their wide-ranging contribution to human wellbeing, which was previously unacknowledged or simply taken for granted. Thus, the scientific research agenda has perceptively switched from what peat ecosystems are to what they $d o$. Earlier research emphasis on their genesis and development (e.g. Moore 1973, 1975, Merryfield \& Moore 1974, Clymo 1983, 1984), ecology (e.g. Godwin 1981, Lindsay et al. 1988, Stroud et al. 1988, Rodwell 1991) and specific management interventions (reviewed in Evans 2009) has now given way to investigations of ecosystem processes, including their carbon balance and flux of greenhouse gases (e.g. Worrall et al. 2003, 2009), microbiological interactions (e.g. Freeman 2001) and role in water quality (e.g. Worrall et al. 2004, Freeman et al. 2004, Monteith et al. 2007).

There are new challenges posed by improved understanding of the wider significance of upland peatlands in mitigation of climate change through the carbon and hydrological cycles, especially in relation to sequestra- tion and/or storage, and flood risk reduction, respectively. This has stimulated new debates on their most appropriate management in a world of rapidly changing climate and greater socio-economic appreciation of the value of the natural environment.

The dilemma for society is how to reach a balance among vested and competing interests in landscapes with complicated property and access rights linked to varied policy frameworks at both national and international levels.

The challenge to the scientific community is to: (1) provide the best available guidance and critical assessment of the evidence base to help policy-makers create the conditions for the development of a more integrated and coherent approach to peatland management, and (2) assist in the formulation of innovative practical tools to implement such an integrated framework on the ground. All of this needs to be framed within the possible effects of progressive environmental change, specifically climate change. Inevitably, final decisions are political and influenced by a plethora of non-scientific factors. Nevertheless, there is a clear responsibility for the relevant science to be presented in ways that allow both politicians and the public to make informed decisions. This study attempts to provide a context for the discussion of some of the salient questions facing the scientific community and the potentially conflicting choices facing society. In particular, it examines how the principles of the ecosystem approach (sensu Convention on Biological Diversity 2003) can help frame the specific questions which need to be tackled. Enshrined in the ecosystem approach is the recognition that humans are part of ecosystems, and their activities are subject to the natural limits and functioning of ecosystems. Thus, the management of ecosystems, as a social process, must involve the communities that have an interest in the processes and outcomes of decision making.

\section{PARADIGM SHIFT}

We are in the midst of a major revolution in how governments view the natural environment, based on the increasing awareness that its functioning actually underpins the human economy and the well-being of society, which followed publication of, inter alia, the Millennium Ecosystem Assessment (2005) and the Stern review of the economics of climate change (Stern 2007). Internationally, the International Science-Policy Platform on Biodiversity and Ecosystem Services (IPBES; www.ipbes.net) has been instituted, along the lines of the IPCC, to strengthen the science policy interface, whereas The Economics of Ecosystems and Biodiversity (TEEB) study emphasises the global dimension of 
the need to more properly value the world's ecosystems (www.teebweb.org/). In the UK, the National Ecosystem Assessment (NEA) attempts to take stock of the wider values of ecosystems. The NEA will assess the current condition of ecosystems as expressed by the services they deliver, together with an assessment of changes that have occurred over time as well as those likely to occur under a range of future scenarios (UKNEA 2010). Natural England, the country's statutory nature conservation agency, has fully embraced the paradigm shift, which is now merging nature, economic growth and prosperity within the same conceptual framework (Natural England 2009).

Such a shift has been previously described for wetlands in general (Maltby 1984b, 2009), which emphasised the importance of moving from a sectoral to a more integrated approach. It recognises that the separation of ecology and socioeconomics does not enable society to make more intelligent and informed decisions about environmental management, which would also contribute to human well-being. Ecosystem management is at the core of achieving sustainable development (Maltby 1997b,c, 2006), and recognition of the services that represent the outcome of ecosystem functioning provides the means of tracking the consequence of management actions in more practical and publicly understandable ways than previously. The need for a new methodological framework has been captured in the adoption of the ecosystem approach by the Convention on Biological Diversity (CBD).

The ecosystem approach 'is a strategy for the integrated management of land, water and living resources that promotes conservation and sustainable use in an equitable way' (Maltby 1999a,b, 2008, Stadler et al. 1999, CBD 1998, 2003, www.cbd.int/ecosystem). It aims to balance the 3 objectives of the CBD - conservation of biodiversity, sustainable use of the components of biodiversity, and fair and equitable sharing of the benefits arising from the commercial and other utilisation of genetic resources-to achieve environmental sustainability, economic prosperity and social well-being (Maltby 2006).

Governments, including the UK, that are signatory to the CBD are wrestling with the actual implementation of the ecosystem approach, but there is increasing evidence of the serious effort to mainstream the concept within the policy framework (DEFRA 2007a,b), including consideration of peatlands (Bonn et al. 2009b). Proper recognition and valuation of ecosystem services is seen as a key prerequisite for delivery of the new approach to ecosystem management in the face of competing stakeholder demands and the possible effects of climate change.

Although there is clear progress in the high-level recognition of the conceptual significance of the ecosystem approach within policy and the technical merits of recognising ecosystem services, there is still a long way to go before practical implementation of a fully integrated methodological framework and appropriate tool kits to assist with peatland management at the functional landscape scale are achieved.

'Whilst an ecosystem approach can provide effective solutions, it does not generate a universal template for what to do' (Natural England 2009, p 15). More precisely, the ecosystem approach is strong as an integrated methodology, but does not, in itself, provide specific tools to implement solutions. It is, however, particularly useful in evaluating the options for achieving possible solutions from an integrated and holistic perspective.

The ecosystem approach is built around 12 principles that were elaborated originally from the Sibthorp principles (Maltby et al. 1999) by international experts meeting in Malawi in 1998 (Convention on Biological Diversity 1998). In the application of the ecosystem approach, it is essential to consider the principles as a whole. They are examined here as a framework to illustrate some of the challenges in applying the ecosystem approach to the context of upland peat ecosystems and, in particular, to identify priority questions which require resolution (Table 1).

\section{UPLAND PEAT ECOSYSTEMS IN A WIDER ENVIRONMENTAL CONTEXT}

A number of key features of UK upland peatlands provide background to the societal choices for their management within a changing environmental and climatic envelope.

- The composition, structure and functioning of the contemporary ecosystem is normally fundamentally different from the system at the point of peat initiation or at successive stages of development. Peat has accumulated from a non-peat starting point that may have been open water, bare rock or mineral soil, or woodland or herbaceous vegetation.

- Peat might no longer be actively accumulating and, indeed, might be wasting as part of a natural autogenic cycle or due to ecosystem alteration by external factors such as pollution, burning, trampling, storm erosion or longer-term climate change.

- The peat deposit or profile is an inherited and not instantaneous feature. A minimum time period of $10^{2}$ to $>10^{3} \mathrm{yr}$ is normally required for the development of peat compared with an organic soil layer. Most UK upland peats began to form in prehistoric or early historic times, over which period there has been superimposition of many different phases of climate and human-induced change. 
Table 1. Salient questions relating management of UK upland peat-based ecosystems to the principles of the ecosystem approach (sensu Convention on Biological Diversity)

\begin{tabular}{|c|c|}
\hline Principle & Context \\
\hline $\begin{array}{l}\text { 1. Management } \\
\text { objectives are a } \\
\text { matter of societal } \\
\text { choice }\end{array}$ & $\begin{array}{l}\text { Management historically has been determined largely by } \\
\text { sectoral interests generally at the local or regional scale de- } \\
\text { termined by land owners or statutory bodies. Except for con- } \\
\text { servation and farming interests, there has been limited at- } \\
\text { tention to the wider societal benefits of a more integrated } \\
\text { management strategy. Catchment management (mainly for } \\
\text { water management) and development planning (mainly for } \\
\text { socio-economic reasons and landscape aesthetics) have the } \\
\text { potential to realize wide-ranging and significant benefits } \\
\text { from a more integrated strategy }\end{array}$ \\
\hline
\end{tabular}

2. Management

should be

decentralized to

the lowest

appropriate level

3. Ecosystem managers should consider the effects of their activities on adjacent and other ecosystems

4. There is a need to understand and manage the ecosystem in an economic context

5. Conservation of ecosystem structure and functioning should be a priority target

6. Ecosystems must be managed within the limits of their functioning

\section{The Ecosystem} Approach should be undertaken at the appropriate spatial and temporal scale

8. Objectives for ecosystem management should be set for the long term
Decisions potentially impacting peatlands are often made remotely and by interest groups who are insufficiently informed about local conditions and consequences of inappropriate actions. Involvement of local stakeholders and especially landowners is an essential ingredient in the response to climate change by means of adaptive management techniques or mitigation strategies, but the engagement of policy makers at the executive level is also essential

Historically, peatland management has ignored the possibility of off-site impacts such as carbon loss, water quality, sedimentation, flood-risk and fisheries

Arguably the narrow capitalization of certain provisioning services has been the fundamental driver of the use and management of upland peat ecosystems, influenced at times by market distortions (such as upland grazing subsidies) and suffering from a fundamental mismatch between the spatial, sectoral and temporal distribution of costs and benefits (e.g. costs to the landowner of maintenance of the integrity of the peat ecosystem but benefits to downstream populations, water companies and the conservation sector)

The rationale underpinning this principle is based on the importance of the physical integrity of peats and their ecosystems to ensure resilience (resistance) to change and the ability to continue to deliver a wide range of ecosystem services

Limits to or thresholds of functioning may be affected by external drivers or drivers maintained by management (e.g. burning, grazing) or particular climate conditions (e.g. water table, peat accretion/decomposition)

Peatland management needs to be undertaken in the wider context of water management at the catchment scale within the framework of rural and farming policy and regional development. However it is also necessary to recognize the potential significance of highly localized activity such as recreation

Management interventions and environmental and/or climate impacts may result in more or less long term changes in ecosystem processes such as primary productivity and decomposition. Even temporary changes, for example, in aeration may have a much more persistent, possibly even irreversible, effect on enzyme activity than previously anticipated. (Freeman, 2001)
How can decisions affecting peatlands be based on a more informed evidence base relating to the societal benefits and disbenefits arising from particular management strategies and climate change?

How can decisions be made on a more fully inclusive basis across all societal benefits and beneficiaries?

How do we assess all of the many previously overlooked services simultaneously?

What is the operational method for delivery of local-scale management consistent with the wider policy context?

To what extent will climate change alter offsite impacts and how will this vary according to peat-based activities?

How do we implement the changes necessary to more fairly reflect the distribution of costs and benefits taking into account the diverse range of stakeholders and their scale of benefits from the ecosystem services of peatlands especially given their significance in relation to climate change?

To what extent will climate change lead to changes in ecosystem structure and functioning and what will be the possible consequences for the delivery of ecosystem services?

How will climate change affect the nature and ability of peat ecosystems to function? Which uses best safeguard their functioning under uncertain future conditions?

What is the institutional structure which can provide for effective management of peat ecosystems at both the catchment and more local scale capable of responding to the possible impacts of climate change?

Can we inform policy-making with what we know about trends on longer temporal scales, including possible lag effects and reversibility of changes in ecosystem processes due to climate change, whilst doing so on an adaptive basis to allow for evolving understanding? 


\begin{tabular}{|c|c|c|}
\hline Principle & Context & Questions \\
\hline $\begin{array}{l}\text { 9. Management must } \\
\text { recognize that change } \\
\text { is inevitable. }\end{array}$ & $\begin{array}{l}\text { Peat ecosystems develop and change over time due } \\
\text { to autochthonous and successional pressures. There } \\
\text { may also be uncertainties and 'surprises' such as bog } \\
\text { bursts or fissuring at a certain point of growth leading } \\
\text { to a cycle of peat erosion independent of climatic fac- } \\
\text { tors. Changes may be gradual and progressive or sud- } \\
\text { den and catastrophic, related to more extreme events } \\
\text { such as storms, drought or fire. It can never be as- } \\
\text { sumed that the ecosystem is in equilibrium }\end{array}$ & $\begin{array}{l}\text { What are the indicators of change and how can } \\
\text { these be used to distinguish between climate- } \\
\text { induced effects as opposed to other causes of } \\
\text { changes? }\end{array}$ \\
\hline $\begin{array}{l}\text { 10. The Ecosystem Approach } \\
\text { should seek the appropriate } \\
\text { balances between, and } \\
\text { integration of, conservation } \\
\text { and use of biological diversity }\end{array}$ & $\begin{array}{l}\text { Underlining a flexible approach to management in } \\
\text { which protection and production are not mutually ex- } \\
\text { clusive, this principle essentially is the advocate for } \\
\text { 'wise use' of peatlands }\end{array}$ & $\begin{array}{l}\text { What is the appropriate balance of conserva- } \\
\text { tion and use for different types and location of } \\
\text { peat ecosystems and how will this be influ- } \\
\text { enced by climate change? }\end{array}$ \\
\hline $\begin{array}{l}\text { 11. The Ecosystem Approach } \\
\text { should consider all forms } \\
\text { of relevant information, } \\
\text { including scientific and } \\
\text { indigenous and local } \\
\text { knowledge, innovations } \\
\text { and practices }\end{array}$ & $\begin{array}{l}\text { Failure to make use of all available knowledge in- } \\
\text { cluding practical and historic experience of ecosystem } \\
\text { conditions, change and activities may limit the ability } \\
\text { to make the right decisions for future management }\end{array}$ & $\begin{array}{l}\text { How can we best assemble and secure for fu- } \\
\text { ture use local/indigenous knowledge, espe- } \\
\text { cially memory of prior conditions and practical } \\
\text { expertise alongside scientific data and experi- } \\
\text { ence as an accessible record to aid future man- } \\
\text { agement? }\end{array}$ \\
\hline $\begin{array}{l}\text { 12. The Ecosystem Approach } \\
\text { should involve all relevant } \\
\text { sections of society and } \\
\text { scientific disciplines }\end{array}$ & $\begin{array}{l}\text { It is increasingly important to ensure that all sectoral } \\
\text { interests, including conservation, farming, water in- } \\
\text { dustry, fisheries, flooding and others are involved in } \\
\text { the decision-making process regarding the future of } \\
\text { peatlands }\end{array}$ & $\begin{array}{l}\text { How are different sectoral interests likely to be } \\
\text { affected by the changes in peat ecosystems } \\
\text { which result from climate change? } \\
\text { What institutional arrangements are necessary } \\
\text { to bring about more collective decision-making? }\end{array}$ \\
\hline
\end{tabular}

- Formation, development and maintenance of peat depends on an envelope of environmental conditions representing local- and/or regional-scale characteristics in which climate is of critical but not sole importance. (cf. templates of formation, Moore \& Bellamy 1974). The actual trigger for peat development might have been human-induced alteration of vegetation and/or soil conditions resulting in hydrological change (without necessarily requiring climate change).

- Peat bodies represent high densities of organic carbon but, depending on depth, the amounts stored by organic-rich mineral soils may be at least comparable because of bulk density and water content differences.

- Peat is highly sensitive and vulnerable to often subtle changes in hydrology and environmental conditions, such as aeration and nutrients, often resulting in irreversible physico-chemical alteration (e.g. conferring water repellent properties and producing significant enzyme changes).

- Peat supports species with exceptional adaptations to the peat-forming environment. Some, such as Sphagnum mosses, Eriophorum spp. and other sedges and grasses such as Molinia caerulea, are actual drivers of peat accumulation in active mire ecosystems. Others may be there as a result of recent land management activities and have no genetic relationship to formation of the underlying peat (such as the case of much of the Calluna-dominated moorland in the UK, which is maintained by regular muir-burn).

Particularly tantalising in this characterisation is the relative importance of climate in determining the status, condition and stability of the peat ecosystem, compared with direct interventions and indirect impacts of human activities.

It has long been stated that peat-forming ecosystems in the UK uplands were originally primarily the result of climate-topographic interactions (Moore \& Bellamy 1974). A correlation has been made between the 1200 to $1250 \mathrm{~mm}$ isohyet (line of equal precipitation) and the extent of blanket peat (Godwin 1981, O'Connell 1990), whereas Rodwell (1991) reported the threshold for blanket peat formation as at least 160 rain days combined with annual rainfall greater than $1200 \mathrm{~mm}$. Lindsay et al. (1988) correlated the change in size, proportion and pattern of open pools and hollows in blanket bog ecosystems with the number of rain days and mean temperature. Much less attention was given originally by ecologists to the potentially overwhelm- 
ing importance of prehistoric human activities to the onset and subsequent development of upland peat. It is now accepted that anthropogenic activity has played an important role in the development of blanket peat over a substantial area of the UK (Merryfield \& Moore 1974, Moore 1973, 1975) through clearance of woodland and hydrological alterations at a time when climate overall was favourable for the growth of Sphagnum mosses. The precise switching mechanism also may have been due to the resulting changes in pedogenesis, with initially increased infiltration producing greater soil acidification and podzolisation and/or gleying of previously brown soils. Iron pan development, resulting from podzolisation, subsequently impeded drainage and caused surface waterlogging-conditions favouring the growth of peatforming plants such as Sphagnum spp. and Molinia caerulea. The result was termed 'pedogenic peat' by Taylor \& Smith (1980). It is also feasible that peat initiation is the outcome of such pedogenic processes without human intervention.

In situ growth of the peat mass continues for as long as the rate of addition of plant material exceeds its rate of decay. The imbalance, in favour of accumulation, is usually integrated as a result of low rates of decomposition caused by factors such as waterlogging, low temperatures, acidity, low nutrient levels and plant material resistant to microbial breakdown. All these factors may be influenced by climate. Previous research has demonstrated the particular significance of hydrology and water movement in determining the stability, size and slope of the peat mass (Ivanov 1981, Ingram 1982). There are natural limits to peat growth related to the overall carbon budget (Clymo 1984, 1992) and the physical stability of the peat mass. Instability may arise from extreme conditions of drought or rainfall and may result in bog 'bursts'. Human activities such as peat cutting and drainage may increase the risk of collapse.

There is extensive evidence of current upland peat degradation. This is most dramatic in the deeper blanket mires, such as where gullies have developed to the underlying regolith and dissect the peat mass into isolated mounds (haggs), and peat faces exposed to accelerated erosion and decomposition. Erosion may be the final outcome of a natural growth cycle, eventually resulting in collapse of the peat mass (Lewis 1906, Johnson 1957), or it may be due to one or a combination of extraneous factors. Mackay (1997) has described the widespread nature of upland peat erosion in the UK. He also reviewed the various possible causes of erosion, which include climate change, biotic factors such as grazing and burning, atmospheric pollution and forest clearance, and concluded that different types and timings of degradation resulted from different processes. There is considerable evidence for the importance of accidental (or deliberate) fires in the large-scale degradation of upland peat (Mackay 1997). Severe fire and the scale of peat loss increases with drought. Maltby et al. (1990) have described the consequences of peat fires on $12 \mathrm{~km}^{2}$ of the North York Moors associated with the 1976 drought. Further trends towards more frequent drought, or simply occasional drier periods, will undoubtedly result in future catastrophic burns, given the progressive increase in recreational use of the uplands.

The collective evidence suggests that:

(1) The circumstances leading to the onset and course of peat formation may be progressive as a result of exposure of new surfaces (e.g. water-terrestrialisation; sediment or soils-paludification), or it may be sudden and rapid in ecological terms (measureable in $10^{1}$ to $10^{2} \mathrm{yr}$; see Maltby \& Caseldine 1982); however, events or actions causing subsequent degradation (e.g. storm, fire, drainage) may be orders of magnitude faster (minutes to days).

(2) In the absence of human interventions by prehistoric communities, large areas presently covered in peat could be very different ecosystems today, such as mixed deciduous woodland and scrub. Where peat has developed, human activities have resulted in significant alterations; for example, deliberate interventions on blanket bog - such as increased grazing pressure during the medieval period-have dramatically reduced the rate of peat accretion and created grass- and heath-dominated ecosystems (e.g. Maltby \& Crabtree 1976). More recently, prescribed rotational burning to encourage a mosaic of even-aged stands of Calluna in different stages of development to maximise breeding populations of red grouse (Lagopus lagopus scoticus) for shooting has, since the 19th century, transformed the surface of large tracts of peatland into heather monoculture. There is generally no genetic relationship between this managed vegetation community and that responsible for development of the underlying peat substrate.

Clearly, the extent to which current peat ecosystems are the direct outcome of climate rather than humaninduced changes within previous as well as the present environmental envelope is a significant question. Its resolution would help define the sensitivity of peatforming processes to climate change, the vulnerability of the existing peat store to climate-induced degradation and the possibilities of management interventions either accelerating or ameliorating change.

(3) Alteration in pedogenesis in the uplands has been and can be rapid and result in a rate of change in soil properties sufficient to encourage peat development or lead to its loss. New cycles of soil development may be introduced within $10^{1}$ to $10^{2} \mathrm{yr}$, and many more-or-less 
distinct cycles of pedogenesis may have influenced profile characteristics but often remain understated in upland soils and peats from post-glacial times to the present.

Dimbleby (1962) drew attention to human-induced podzolisation in the Bronze Age stimulating the development of peaty soils, whereas Maltby \& Caseldine (1982) provided direct pedogenic, pollen and ${ }^{14} \mathrm{C}$ evidence for the possible high speed of change from brown soils to those accumulating a strongly acid peat surface in the Bronze Age (ca. 3500 BP) on Bodmin Moor. There is also abundant evidence of the reversibility of the pedogenic conditions favouring peat formation to those resulting in the (re)development of brown soils, which, in some locations, would have predated current peat deposits. This has been shown to result from colonisation by birch (Miles 1981) via the introduction of improved pasture for grazing (Crompton 1953) or more comprehensive agricultural reclamation of peatland (Maltby 1984a). It has also been shown that deciduous trees, including the genera Betula, Salix, Quercus, Castanea and Alnus, as well as the coniferous Pinus, can be established on moorland at altitude currently supporting extensive tracts of blanket peat (Maltby \& Gabriel 1984). The potential significance of the outcome of these experimental trials on the North York Moors is that: (1) mixed deciduous as well as coniferous seed germination is possible in a landscape where the environment might, but is not necessarily still able to, form peat; (2) tree remains at the base of the blanket peat (Maltby 1980) do not necessarily indicate pre-peat-forming conditions fundamentally more favourable for woodland development compared to the present; and (3) blanket peat represents just one ecosystem type able to develop in the upland landscape.

Fencing of experimental plots was an important factor in ensuring tree survival and underlies the importance of grazing in the management of upland vegetation. Overgrazing is recognised as a major cause of decline of heather moorland (Shaw et al. 1996) and has often been cited as one of the triggers for peat erosion. (Shimwell 1974, Evans 1996). However, in their recent review of the carbon budget of upland peat soils, Worrall \& Evans (2009) suggested that very little is known about the impact of the interactions between grazing and burn management.

\section{VISIONS FOR THE FUTURE}

We can identify at least 4 overriding considerations for the future management of upland peat:

(1) Enhancing the vitality of the rural economy in the uplands.
(2) Maintaining or enhancing the contribution of upland peatlands to environmental security, such as mitigation of climate change and the supply of highquality water under safe conditions.

(3) Supporting the well-being of the wider community from local to national levels.

(4) Safeguarding important biodiversity and cultural heritage.

All were implicitly considered in the recent review of upland future scenarios by Reed et al. (2009).

It is assumed that, ultimately, the 'intelligent' goal is to achieve the most appropriate balance of objectives for the management of upland peat ecosystems. Where this balance lies is at the centre of the debate that constitutes societal choice. This does not necessarily mean that the balance should not vary according to location and context. Conservation- or restoration-orientated actions might assume precedence in some areas but not in others: 'one size does not necessarily fit all'. A suggested prerequisite to achieving such balance in a changing climate world is to tackle questions which stem from each of the principles of the ecosystem approach. These contribute to an agenda for development of a more integrated approach to peatland management (Table 1). Examination of the principles as a whole forces holistic consideration and scrutiny of scientific, economic, socio-cultural and policy perspectives, rather than proceeding simply or solely from a sectoral viewpoint. The analysis by Reed et al. (2009) confirmed the need for more effective involvement of stakeholders in the determination of preferred future conditions and better use of visualisation and simulation techniques.

By highlighting the functioning of peatlands, expressed as ecosystem services, it is easier to see the opportunities for compatibility of objectives and the challenges arising from incompatibilities. An attempt is made in Table 2 to illustrate the general relationships among ecosystem services in a compatibility matrix. Trade-offs may be inevitable, but at least, if they can be identified, it is possible to reconcile the effects of potentially difficult management and strategic decisions. It is possible to identify winners and losers from management for particular outcomes of service provision, put values on services and carry out audits of the outcomes of actions or inaction.

Natural scientists, social scientists, economists, conservationists, politicians, businesses, statutory and nonstatutory agencies, and NGOs all need to be involved in a new consultative and organisational process which can be guided by the ecosystem approach principles and informed by the functional assessment of peatlands as translated into ecosystem service delivery. The actual issues 'on the ground' will often be local in scale and context dependent. Examples include the 
Table 2. Generalised indicative compatibility matrix for management of particular ecosystem services in upland peatlands (developed from Maltby 1997a and diverse literature sources). A managed ecosystem service (columns) can have a significant benefit (+), no significant benefit or a cost (-), or generally zero effect (no effect) on other ecosystem services (rows)

\begin{tabular}{|c|c|c|c|c|c|c|c|c|}
\hline \multirow[b]{2}{*}{ Affected ecosystem service } & \multicolumn{8}{|c|}{ Managed ecosystem service } \\
\hline & $\begin{array}{c}\text { Carbon } \\
\text { storage/ } \\
\text { sequestration }\end{array}$ & $\begin{array}{l}\text { Water } \\
\text { quality }\end{array}$ & $\begin{array}{l}\text { Flood risk } \\
\text { reduction }\end{array}$ & $\begin{array}{l}\text { Crops/live- } \\
\text { stock/game } \\
\text { production }\end{array}$ & $\mid \begin{array}{c}\text { Habitat/ } \\
\text { species }\end{array}$ & $\mid \begin{array}{c}\text { Paleoenvi- } \\
\text { ronmental } \\
\text { information }\end{array}$ & $\begin{array}{l}\text { 'Traditional' } \\
\text { recreation }\end{array}$ & $\begin{array}{l}\text { Landscape } \\
\text { (especially } \\
\text { 'wildness') }\end{array}$ \\
\hline Carbon storage/sequestration & & + & + & $-{ }^{b}$ & + & + & $--^{\mathrm{c}}$ & + \\
\hline Water quality & $t^{\mathrm{a}}$ & & + & $-{ }^{\mathrm{d}}$ & + & + & $-{ }^{\mathrm{c}}$ & + \\
\hline Flood risk reduction & + & + & & - & + & + & $-^{\mathrm{c}}$ & + \\
\hline Crops/livestock/game production & $-d$ & $-{ }^{\mathrm{d}}$ & $-{ }^{\mathrm{d}}$ & & $-{ }^{\mathrm{d}}$ & $-{ }^{\mathrm{d}}$ & No effect & + \\
\hline Habitat/species & + & + & + & $-{ }^{\mathrm{d}}$ & & + & $-^{\mathrm{c}}$ & + \\
\hline Paleoenvironmental information & + & + & + & $-{ }^{\mathrm{d}}$ & + & & No effect & + \\
\hline Recreation & - & - & - & $-^{\mathrm{d}}$ & - & - & & No effect $\mathrm{t}^{\mathrm{e}}$ \\
\hline Landscape & + & + & + & $-{ }^{\mathrm{d}}$ & + & No effect & + & \\
\hline
\end{tabular}

focus on dissolved organic carbon responsible for coloured water in the peat catchments supplying customers of United Utilities in NW England (peatlands. org.uk), and peat erosion together with elevated fire risks arising from use of long-distance footpaths, such as the Lyke Wake Walk on the North York Moors (www.lykewake.org/organise.php). It will be essential, therefore, that local and representative stakeholders are part of the process leading to the most appropriate balance in peatland use, management and conservation.

Despite this, it is not simple, for instance, to match the trade-off of new jobs created by more intensive management of upland peatland against the potential loss of regulatory services such as carbon sequestration or water quality. However, with the benefit of a stronger evidence base, it should be possible to determine where increased management effort can support, for example, increased production of sheep and/or grouse, resulting in higher revenue for the rural economy, while minimising or even preventing adverse impacts on other services. This might be achieved by better spatial zonation of activities or innovative management techniques. Alternatively, systems involving payment for ecosystem services may be introduced. This would involve the quantification of services provided by identifiable areas of peatland and the clear recognition of the beneficiaries. Apart from the technical challenges in determining these data, there is still a major policy gap in how real payments could be made to landowners and managers. Not least is the difficulty of matching service performance with the cost of management actions and the realisation of benefits to those who are paying. There is the additional challenge of matching current social and economic exploitation against the capacity of protected ecosystem character, such as landscape, to support longer-term interests including the potential values and needs of future generations. Thus, for Bronze Age communities, the transformation in the uplands of mixed deciduous woodlands and its fauna to peat-forming ecosystems was probably regarded as catastrophic (an ecological disaster in modern terms). Yet 3000 yr later, these upland ecosystems have become conservation and landscape icons of the UK National Park network (as opposed to a Bronze Age 'planning disaster').

A recent analysis by Worrall et al. (2009) examined the feasibility of meeting the management costs of peatland restoration from the value of carbon offsets. Their study indicated that just over half of those areas, where modelling of specific and targeted management actions indicated a carbon benefit, would show a profit from carbon offsetting within $30 \mathrm{yr}$. At least 3 areas of uncertainty complicate the rolling out of this approach: not all interventions produce benefit, indeed some increase carbon loss; the proportion of areas showing profit and the time frame are highly dependent on the price of carbon and the costs of restoration; and climate change will likely affect the carbon flux and its reversibility by management actions.

There are many practical restoration techniques for the 'recovery' of moorland and peat ecosystems (Anderson et al. 2009). There may be others yet to be attempted. For example, experimental soil acidification or other amendments that reduce decomposition and enhance leaching of iron and manganese to encourage pan formation might offer possible but as yet untested mechanisms to increase long-term surface wetness and counter the effects of higher evaporative losses associated with rises in temperature. This could be an approach to help re-establish peat growth in severely degraded areas. 


\section{CONCLUSIONS}

Some challenging decisions lie ahead as both the climate envelope and the historic ecological conditions favouring the development, maintenance and/or recovery of UK upland peat-based ecosystems are likely to contract (Clark et al. 2010, Gallogo-Sala et al. 2010, both in this Special). We need to be sure that management interventions in peatlands achieve the stated objectives and that those objectives meet recognised and generally approved societal priorities. There are many different ecosystem types which can exist in the UK uplands that are more or less dependent on climate and management intervention and interactions.

Peat-based ecosystems are highly significant carbon stores, but might variously represent transient, humaninduced and, currently, more or less rapidly degrading systems. There is uncertainty over the proportion and location of those areas where peat accumulation is still active. Improved spatial knowledge of the capacity for further peat development is a high priority.

Peat-based ecosystems provide a particular suite or 'bundle' of services with clear benefits to human wellbeing at different scales and locations. There has, to date, been insufficient recognition of the values of these ecosystem services. The scientific community can now provide a catalyst to the much wider debate that is necessary among the range of stakeholders, who have often conflicting priority interests in the upland landscape, together with the diverse policy interests, to develop a more coherent approach to the management of these ecosystems. The key ingredient of the catalyst will be the translation of the highly technical and sometimes apparently contradictory scientific data into information which can be readily understood by the wider public, diverse sectoral interests and politicians. The simple analysis presented here, within the framework of the ecosystem approach, may help advance our thinking by identifying an agenda of questions - particularly in reference to climate-change issues-leading more clearly to an integrated solution to peat management. There are numerous scientific, socioeconomic and institutional and/or governmental priorities exposed by the questions identified in Table 1.

The specific approach to the questions will be determined by the regional and governance context and the variable nature of knowledge gaps. Elaboration of these could be advanced under the new UK peat programme launched by IUCN in 2009 (www.iucn-uk-peatlandprogramme.org/), and further insight will emerge from the outputs of the National Ecosystem Assessment.

Despite such ongoing initiatives, the scientific community may still fall short of the mark in assisting the necessary policy innovation and peat management responses to climate change. Potential reasons include:
(1) Insufficient transdisciplinary working. This is necessary to achieve better linkage between downscaled climate models, peat carbon dynamics and ecological processes. In addition, it helps develop closer collaboration among natural, social and economic science researchers, and the policy and stakeholder communities at both regional and national levels.

(2) Overwhelming dominance in particular cases of a single-purpose management objective (e.g. reactivation of peat growth, restoration of heather moorland, improved water quality - especially related to colour and sediment load-enhanced public access or productive hill farming). There are inevitable conflicts and incompatibilities between such single objectives, but there is a possibility of synergies if organised as part of an integrated approach.

(3) Inadequate resources and institutional structures to support the necessary integrated research, competing with other societal priorities.

The case for new investment and activity needs to be strong and expressed in the language that both the wider public and politicians can find convincing at a time of severe financial constraints. The science needs to be based on the best available evidence and not on commonly held assumptions, no matter how reasonable they seem. Milly et al. (2008) have provided a strong reminder that the environmental baseline and its variability are not necessarily constant. Compounded with the evidence of climate change, we cannot assume that the environmental envelope within which peat initiation and subsequent development has taken place is still present or, if so, that it is not moving. There are thus 2 important considerations: (1) upland peats in the UK generally might be in a late stage and, possibly, degradational phase of natural (unassisted) development (stimulated or accelerated in some cases by human activities); (2) the upland environment is no longer generally conducive to natural peat regeneration or re-initiation. There is a research priority to establish the proportion and location of those areas where peat accumulation is still active, together with a need to assess the sustainability of hydrological and vegetation restoration techniques under anticipated climate scenarios.

If restoration is only able to attain some inherently unstable and unsustainable condition, then is it the best option for management? The answer will depend on the proper and fuller social and economic valuation of the many ecosystem services which can be attributed to peatlands. It is perhaps helpful to distinguish between the peat mass as an inherited accumulation of organic matter and the outcome of a prolonged imbalance between production and decomposition and the associated habitats, especially plant communities, which may or may not be actively peat-forming. 
The peat bodies may represent significant stores of carbon, nutrients, contaminants and water. Even if they are no longer building, they represent capital and assets that contribute services to society. There is clear recognition of such services when peat is degraded; for example, the rapid release of carbon dioxide to the atmosphere, adding to the greenhouse gas concentration, or dissolved organic carbon, reducing water quality. Minimisation of such losses can have benefits at local and global scales, and should be valued appropriately. There is still considerable scope for empirical research to establish the complete range of benefits (and potential costs) resulting specifically from the peat resource and its vulnerability to human activities as well as climate change.

The surface vegetation is an important element in maintaining integrity of the peat body, but is also subject to alteration by climate change and may be manipulated deliberately or inadvertently by management actions. We need research which links the socioeconomic costs and benefits of different land-use and management options to vegetation and community types under likely climate scenarios. It needs to be clear which vegetation types and management interventions contribute positively to or minimise losses of services from the underlying peat. It is also important to determine which management actions are, in effect, drawing down on the peat capital and quantify the significance of this in both economic and ecological terms.

A comprehensive, well-informed and regionally based analysis of the values of peat-based ecosystems, underpinned by the best available science, is a key starting point from which to develop the holistic framework offered by the ecosystem approach.

Acknowledgements. S. Cornell and one anonymous reviewer in particular are thanked for helpful comments on the manuscript which was prepared whilst the author benefited from sabbatical leave supported by the University of Liverpool.

\section{LITERATURE CITED}

Anderson P, Buckler M, Walker J (2009) Moorland restoration: potential and progress. In: Bonn A, Allott T, Hubacek $\mathrm{K}$, Stewart J (eds) Drivers of environmental change in uplands. Routledge, London, p 432-447

Bonn A, Allott T, Hubacek K, Stewart J (2009a) Drivers of environmental change in uplands. Routledge, Abingdon

Bonn A, Resame M, Reid C (2009b) Ecosystem services: a new rationale for Conservation of upland environments. In: Bonn A, Allott T, Hubcek K, Stewart J (eds) Drivers of environmental change in uplands. Routledge, Abingdon, p 448-474

CBD (Convention on Biological Diversity) (1998) Report of the workshop on the ecosystem approach. Lilongwe, Malawi, 26-28 Jan 1998. UNEP/CBD/COP/4/INF9, UNEP, Montreal

CBD (Convention on Biological Diversity) (2003) Ecosystem approach: further elaboration, guidelines for implementation and relationship with sustainable forest management. UNEP/CBD/SBSTTA/9/INF14, UNEP, Montreal

Clark JM, Gallego-Sala AV, Allott TEH, Chapman SJ and others (2010) Assessing the vulnerability of blanket peat to climate change using an ensemble of statistical bioclimatic envelope models. Clim Res 45:131-150

Clymo RS (1983) Peat. In: Gore AJP (ed) Mires, swamps, bog, fen and moor. Elsevier, Amsterdam, p 159-224

Clymo RS (1984) The limits to peat bog growth. Philos Trans R Soc Lond B 303:605-654

Clymo RS (1992) Models of peat growth. Suo 43:127-136

Crompton E (1953) Grow the soil to grow the grass. Some pedological aspects of marginal land improvement. Agriculture 60:301-305

Darby HC (1983) The changing fenland. Cambridge University Press, Cambridge

DEFRA (2007a) Securing a healthy natural environment: an action plan for embedding an ecosystems approach. Department for Environment, Food and Rural Affairs, London

DEFRA (2007b) An introductory guide to valuing ecosystem services. Department for Environment, Food and Rural Affairs, London

Dimbleby G W (1962) The development of British heathlands and their soils. Oxford Forestry Memoirs 23, Clarendon Press, Oxford

Evans R (1996) Soil erosion and its impacts in England and Wales. Friends of the Earth Trust, London

Evans M (2009) Natural changes in upland landscapes. In: Bonn A, Allot T, Hubacek K, Stewart J (eds) Drivers of environmental change in uplands. Routledge, Abingdon, p 13-33

Freeman C (2001) An enzymic 'latch' on a global carbon store. Nature 409:149

Freeman C, Fenner N, Ostle N, Kang H and others (2004) Export of dissolved organic carbon from peatlands under elevated carbon dioxide levels. Nature 430:195-198

Gallego-Sala AV, Clark JM, House JI, Orr HG and others (2010) Bioclimatic envelope model of climate change impacts on blanket peatland distribution in Great Britain. Clim Res 45:151-162

Godwin H (1981) The archives of the peat bogs. Cambridge University Press, Cambridge

Holden J, Shotbolt L, Bonn A, Burt TP and others (2007) Environmental change in moorland landscapes. Earth-Sci Rev $82: 75-100$

Ingram HAP (1982) Size and shape in raised mire ecosystems: a geophysical model. Nature 297:300-303

Ivanov KE (1981) Water movement in mirelands. Academic Press, London

Johnson RH (1957) Observations on the stream pattern of some peat moorlands in the southern Pennines. Mem Manchester Lit Philos Soc 99:1-18

Lewis FG (1906) The plant remains in the Scottish peat mosses. II. The Scottish Highlands. Trans R Soc Edinb 45:335-360

Lindsay RA, Charman DJ, Everingham F, O'Reilly RM, Palmer MA, Rowell TA, Stroud DA (1988) The Flow Country - the peatlands of Caithness and Sutherland. Nature Conservancy Council, Peterborough

Mackay AW (1997) Peat erosion: some implications for conservation and management of blanket mires and heather moorland in the UK. In: Parkyn L, Stoneman RE, Ingram HAP (eds) Conserving peatlands. CAB International, Wallingford, $\mathrm{p}$ 82-87

Maltby E (1980) The impact of severe fire on Calluna moor- 
land in the North York Moors. Bull Ecol 11:683-708

Maltby E (1984a) Response of soil microflora to moorland reduction for improved agriculture. Plant Soil 76:183-193

Maltby E (1984b) Waterlogged wealth: Why waste the world's wet places? Earthscan, London

Maltby E (1997a) Peatlands: the science case for conservation and sound management. In: Parkyn L, Stoneman RE, Ingram HAP (eds) Conserving peatlands. CAB International, Wallingford, p 121-131

Maltby E (1997b) Developing guidelines for the integrated management and sustainable utilisation of tropical lowland peatlands. In: Rieley JO, Page SE (eds) Biodiversity and sustainability of tropical peatlands. Samara, Cardigan, p 9-18

Maltby E (1997c) Ecosystem management: the concept and the strategy. IUCN World Conservation 3/97:3-4

Maltby E (1999a) Ecosystem approach: from principles to practice. In: Schei PJ, Sandland OT, Starnd R (eds) The Norway/UN conference on the ecosystem approach for sustainable use of biological diversity. 6-10 Sep 1999, Trondheim. Norwegian Directorate for Nature Management and Norwegian Institute for Nature Research, Trondheim, p 30-40

Maltby E (1999b) Some European perspectives of the ecosystem approach. In: Korn H, Stadler J, Maltby E, Kerr AJ (eds) Report of the scientific workshop on 'The Ecosystem approach - what does it mean for European ecosystems'? German Federal Agency for Nature Conservation, Bonn, p 29-40

Maltby E (2006) Wetland conservation and management: questions for science and society in applying the ecosystem approach. Ecol Stud 191:93-116

Maltby E (2008) Resolving peatland management and conservation dilemmas through implementation of the ecosystem approach. Proc 13th Int Peat Conf, June 2008, Tullamore, Int Peat Society, Jyväskylä, p 8-16, www. peatsociety.org/index.php?module=shop_view_product\& id $=82 \&$ product_id $=81$

Maltby E (2009) The changing wetland paradigm. In: Maltby E, Barker T (eds) The wetlands handbook. Wiley-Blackwell, Oxford, p 3-42

Maltby E, Caseldine CJ (1982) Prehistoric soil and vegetation development on Bodmin Moor, southwestern England. Nature 297:397-400

Maltby E, Crabtree K (1976) Soil organic matter and peat accumulation on Exmoor: a contemporary and palaeoenvironmental evaluation. Trans Inst Br Geogr 1:259-278

Maltby E, Gabriel K (1984) Experimental regulations on severely eroded and burnt moorland at Cockheads, Glaisdale Moor. Moorland Management, North York Moors National Park, Helmsley, p 96-101

Maltby E, Legg CJ, Proctor MCF (1990) The ecology of severe moorland fire on the North York Moors: effects of the 1976 fires and subsequent surface and vegetation development. J Ecol 78:490-518

Maltby E, Holdgate M, Acreman M, Weir A (1999) Ecosystem management: questions for science and society. Royal Holloway University of London, Egham

Merryfield DI, Moore PD (1974) Prehistoric human activity and blanket mire initiation on Exmoor. Nature 250:439-441

Miles J (1981) Effect of birch on moorland. Institute of Terrestrial Ecology, Cambridge

Millennium Ecosystem Assessment (2005) http://millenniumassessment.org/en/index.aspx
Milly PCD, Betancourt J, Falkenmark M, Hirsch RM, Kundzewicz ZW, Lettenmaier DP, Stouffer RJ (2008) Stationary is dead: Whither water management? Science 319: 573-574

- Monteith DT, Stoddard JL, Evans CD, de Wit HA and others (2007) Dissolved organic carbon trends resulting in changes in atmospheric deposition chemistry. Nature 450: $537-540$

> Moore PD (1973) The influence of prehistoric cultures on the initiation and spread of blanket bog in upland Wales. Nature 241:350-353

- Moore PD (1975) Origin of blanket mires. Nature 256:267-269

Moore PD, Bellamy DJ (1974) Peatlands. Elek Science, London

Natural England (2009) No charge? Valuing the natural environment. Natural England, Peterborough

O'Connell M (1990) Origin of Irish lowland blanket bog. In: Doyle EJ (ed) Ecology and conservation of Irish peatlands. Royal Irish Academy, Dublin, p 49-71

Patterson G, Anderson R (2000) Forests and peatland habitats: guideline note. Forestry Commission, Edinburgh

> Reed MS, Arblaster K, Bullock C, Burton RJF and others (2009) Using scenarios to explore UK upland futures. Futures 41:619-630

Rodwell JS (ed) (1991) British plant communities, Vol 2. Mires and heath. Cambridge University Press, Cambridge

Shaw SC, Wheeler BD, Kirby P, Phillipson P, Edmunds R (1996) Literature review of the historical effects of burning and grazing of blanket bog and upland wet heath. English Nature Research Report no 172. Natural England, Peterborough

Shimwell DW (1974) Sheep grazing intensity in Edale, Derbyshire 1692-1747 and its affect on blanket peat erosion. Derbyshire Archaeol J 94:35-40

Stadler J, Maltby E, Kerr AJ (eds) (1999) The ecosystem approach: What does it mean for European ecosystems? International Academy for Nature Conservation, Isle of Vilm, Germany, 26-27 Nov 1998. BFN, Skripten

Stern N (2007) The economies of climate change: the Stern review. Cambridge University Press, Cambridge

Stroud DA, Teed TM, Pienkowski MW, Lindsay RA (1987) Birds, bogs and forestry - the peatlands of Caithness and Sutherland. Nature Conservancy Council, Peterborough

Taylor JA, Smith RT (1980) The role of pedogenic factors in the initiation of peat formation and the classification of mires. Proc 6th Int Peat Congr, Duluth, MN, p 109-117

UKNEA (UK National Ecosystem Assessment) (2010) Preliminary synthesis and progress report on status and trends. UK National Ecosystem Assessment, UNEP World Conservation Monitoring Centre, Cambridge

Worrall F, Evans MG (2009) The carbon budget of upland peat soils. In Bonn A, Allott T, Hubacek K, Stewart J (eds) Drivers of environmental change in uplands. Routledge, London, p 93-112

Worrall F, Reed M, Warburton J, Burt TP (2003) Carbon budget for British upland peat catchment. Sci Total Environ 312:133-146

Worrall F, Burt TP, Adamson JK (2004) Can climate change explain increases in DOC flux from upland peat catchments? Sci Total Environ 326:95-112

- Worrall F, Evans MG, Bonn A, Reed MS, Chapman D, Holden $\mathrm{J}$ (2009) Can carbon offsetting pay for upland ecological restoration? Sci Total Environ 408:26-36 